\title{
Bacillus curdlanolyticus sp. nov. and Bacillus kobensis sp. nov., Which Hydrolyze Resistant Curdlan

\author{
YOSHIMI KANZAWA, ${ }^{1}$ AKIRA HARADA, ${ }^{2}$ MARIKO TAKEUCHI, ${ }^{3}$ AKIRA YOKOTA,${ }^{3} \dagger$ \\ AND TOKUYA HARADA ${ }^{1 *}$
} \\ Kobe Women's University, Suma, Kobe 654, ${ }^{1}$ Faculty of Science, Osaka University, Machikane-yama Toyonaka $560,{ }^{2}$ and Institute for Fermentation, Osaka, Juso-honmachi, Yodogawa, Osaka 532, Japan
}

\begin{abstract}
Taxonomic characteristics of seven bacterial strains which were isolated from soil and hydrolyze resistant curdlan were studied. These bacteria were aerobic, spore-forming rods, contained menaquinone 7 as a major quinone, contained anteiso- $\mathrm{C}_{15: 0}$ and iso- $\mathrm{C}_{16: 0}$ as major cellular fatty acids, had guanine-plus-cytosine contents of 50 to $52 \mathrm{~mol} \%$, and could be divided into two groups on the basis of physiological and chemotaxonomic characteristics and DNA-DNA hybridization data. We propose the following two new species: Bacillus curdlanolyticus for strains YK9, YK121, YK161, YK201, and YK203, with type strain YK9 (= IFO 15724); and Bacillus kobensis for strains YK205 and YK207, with type strain YK205 (= IFO 15729).
\end{abstract}

Many microorganisms are able to produce $(1 \rightarrow 3)-\beta-\mathrm{D}-\mathrm{glu}-$ canase (17). Some bacteria produce endo- $(1 \rightarrow 3)-\beta-D-g l u-$ canase, whereas certain fungi and yeasts produce exo- $(1 \rightarrow 3)$ $\beta$-D-glucanase to yield $\alpha$-glucose. Curdlan is composed entirely of $(1 \rightarrow 3)-\beta-D-$ glucosidic linkages $(6)$ and is utilized as a substrate by $(1 \rightarrow 3)$ - $\beta$-D-glucanase. When glucan is heated to more than $95^{\circ} \mathrm{C}$ in water, it becomes resistant to the actions of Zymolyase, a crude preparation of $(1 \rightarrow 3)$ - $\beta$-D-glucanase (19), and to $32 \%$ sulfuric acid at $32^{\circ} \mathrm{C}(8)$. The resistant curdlan forms pseudocrystals which are mainly composed of triple helices, as shown by $\mathrm{X}$-ray diffraction analysis and electron microscopy (5). We have isolated many bacterial strains that are able to hydrolyze resistant curdlan from soil (7). Seven of these strains were found to belong to the genus Bacillus, and strain YK $9^{\mathrm{T}}(\mathrm{T}=$ type strain) produced a high level of exo- $(1 \rightarrow 3)$ $\beta$-D-glucanase to yield $\alpha$-laminaribiose (9).

In this study, we examined physiological and chemotaxonomic properties of these strains, the abilities of the strains to hydrolyze many polysaccharides, including curdlan, and the $\mathrm{G}+\mathrm{C}$ contents of the DNAs of the strains, and we determined the levels of DNA relatedness between our isolates and related species. We propose that five and 2 of these strains belong to the new species Bacillus curdlanolyticus and Bacillus kobensis, respectively.

\section{MATERIALS AND METHODS}

Bacterial strains. The strains used in this study are listed in Table 1. All of the strains were cultured at $30^{\circ} \mathrm{C}$ on medium containing $0.5 \%$ yeast extract, $0.5 \%$ peptone, and $1.5 \%$ agar $(\mathrm{pH} \mathrm{7.2)}$ and were stored at room temperature.

Phenotypic characteristics. Cell morphology was examined by using cells grown on nutrient agar (18). Unless otherwise stated, all tests were carried out at $30^{\circ} \mathrm{C}$. Catalase activity was determined by examining bubbling in a $3 \%$ hydrogen peroxide solution. Oxidase activity was determined by examining the oxidation of $1 \%$ tetramethyl-p-phenylenediamine on filter paper. Acid production from carbohydrates $(0.5 \%)$ after 5 days of incubation was determined by using media containing $0.15 \%\left(\mathrm{NH}_{4}\right)_{2} \mathrm{HPO}_{4}, 0.1 \% \mathrm{KH}_{2} \mathrm{PO}_{4}, 0.05 \% \mathrm{MgSO}_{4} \cdot 7 \mathrm{H}_{2} \mathrm{O}$, and $1.5 \%$ agar; the $\mathrm{pH}$ of each medium was adjusted to 7.0 before a solution of bromcresol purple was added.

Hydrolysis of polysaccharides. A synthetic medium containing each polysac-

${ }^{*}$ Corresponding author. Fax: 81-78-732-5161. Phone: 81-78-7314416.

† Present address: Institute of Molecular and Cellular Biosciences, University of Tokyo, Yayoi, Bunkyo, Tokyo, Japan 113. charide at a concentration of $0.2 \%$, the inorganic salts described above, and $1.5 \%$ agar was used to determine hydrolysis of polysaccharides. Hydrolysis was observed after 5 days of incubation. Hydrolysis of curdlan (regenerated and resistant) was determined by the method described previously by Kanzawa et al. (7). Hydrolysis of pustulan was determined by the method of Alexander and Priest (1). Hydrolysis of $\beta-1,2$-Glucan and carboxymethyl cellulose was determined by using a method similar to the method used to determine pustulan hydrolysis.

DNA base compositions. DNA was obtained by the method of Saito and Miura (16). The $\mathrm{G}+\mathrm{C}$ contents of DNAs were determined by the method of Mesbah et al. (12).

DNA hybridization. DNA-DNA hybridization was carried out at $45^{\circ} \mathrm{C}$ for $2 \mathrm{~h}$ fluorometrically in microdilution wells by using biotinylated DNA $(3,4)$.

Cellular fatty acid compositions and quinone systems. Cellular fatty acids and isoprenoid quinones were prepared and studied as described by Komagata and Suzuki (10).

Sodium dodecyl sulfate-polyacrylamide gel electrophoresis of whole-cell proteins. Wet cells $(0.1 \mathrm{~g})$ were suspended in $1.0 \mathrm{ml}$ of $0.0625 \mathrm{M}$ Tris- $\mathrm{HCl}$ buffer ( $\mathrm{pH}$ 6.8 ) containing $2 \%$ sodium dodecyl sulfate, $5 \% 2$-mercaptoethanol, and $10 \%$ glycerol and heated at $100^{\circ} \mathrm{C}$ for $10 \mathrm{~min}$. After centrifugation at $13,000 \times \mathrm{g}$ for $10 \mathrm{~min}$, the supernatant was subjected to electrophoresis by the method of Laemmli (11)

\section{RESULTS AND DISCUSSION}

Strains YK9 ${ }^{\mathrm{T}}$, YK122, YK161, YK201, YK203, YK205 ${ }^{\mathrm{T}}$, and YK207 were isolated from soil as organisms that were able to attack resistant curdlan (7). $\mathrm{YK}^{\mathrm{T}}$ colonies growing on medium containing glucose or curdlan and inorganic salts or on peptone-yeast extract medium with or without glucose are shown in Fig. 1. Clear motile colonies grew on synthetic medium containing curdlan or glucose, whereas round colonies usually grew on natural medium with or without glucose. Growth of the organism was poor without glucose or curdlan as a carbon source. We compared the taxonomic properties of our isolates with those of related Bacillus species. All of our strains (YK9 ${ }^{\mathrm{T}}$, YK122, YK161, YK201, YK203, YK205 ${ }^{\mathrm{T}}$, and YK207) were gram-positive, motile rods with cell diameters of $>1.0 \mu \mathrm{m}$. Ellipsoidal spores were formed in swollen sporangia. These organisms were catalase positive, but oxidase negative. Gas was not formed from glucose. The major cellular fatty acid components were anteiso- $\mathrm{C}_{15: 0}$ and iso- $\mathrm{C}_{16: 0}$. The isoprenoid quinone was menaquinone 7 . On the basis of the similar properties of our strains and members of the $B a$ cillus circulans complex, we assumed that our strains belong to the $B$. circulans complex (2); our strains belong to a sepa- 
TABLE 1. Bacterial strains used in this study

\begin{tabular}{|c|c|c|}
\hline Strain or species & IFO no. ${ }^{a}$ & Origin or other designation(s) ${ }^{a}$ \\
\hline YK9 $^{\mathrm{T}}$ & $15724^{\mathrm{T}}$ & Soil from Kobe City \\
\hline YK122 & 15725 & Soil from Kobe City \\
\hline YK161 & 15726 & Soil from Kobe City \\
\hline YK201 & 15727 & Soil from Kobe City \\
\hline YK203 & 15728 & Soil from Kobe City \\
\hline YK $205^{\mathrm{T}}$ & $15729^{\mathrm{T}}$ & Soil from Kobe City \\
\hline YK207 & 15730 & Soil from Kobe City \\
\hline \multicolumn{3}{|l|}{$\begin{array}{l}\text { Bacillus circulans } \\
\text { WL-12 }\end{array}$} \\
\hline Bacillus circulans & 3329 & ATCC 9966 \\
\hline Bacillus circulans & 3967 & \\
\hline Bacillus circulans & 13157 & NRRL B-3312 \\
\hline Bacillus circulans & 13294 & \\
\hline Bacillus circulans & 13579 & ATCC 8384 \\
\hline Bacillus circulans & $13626^{\mathrm{T}}$ & $\begin{array}{l}\text { ATCC } 4513^{\mathrm{T}} \text {, NCTC } 2610^{\mathrm{T}} \text {, } \\
\text { NCIB } 9374^{\mathrm{T}}\end{array}$ \\
\hline Bacillus circulans & 13627 & ATCC 4515 \\
\hline Bacillus circulans & 13628 & ATCC 4516 \\
\hline Bacillus circulans & 13629 & ATCC 4530 \\
\hline Bacillus circulans & 13630 & ATCC 8241 \\
\hline Bacillus circulans & 13632 & ATCC 14176 \\
\hline Bacillus circulans & 13633 & ATCC 14175 \\
\hline Bacillus circulans & 13634 & NRRL NRS-826 \\
\hline Bacillus circulans & 13637 & NRRL NRS-841 \\
\hline Bacillus circulans & 13639 & NRRL NRS-977 \\
\hline Bacillus circulans & 13640 & NRRL NRS-1108 \\
\hline Bacillus circulans & 15377 & NRRL NRS-381 \\
\hline Bacillus circulans & 15378 & NRRL NRS-1434 \\
\hline Bacillus circulans & 15379 & NRRL NRS-1173 \\
\hline Bacillus validus & 13635 & NRRL NRS-838a \\
\hline Bacillus validus & 13636 & NRRL NRS-839a \\
\hline Bacillus validus & $15382^{\mathrm{T}}$ & NRRL NRS- $1000^{\mathrm{T}}$, DSM $3037^{\mathrm{T}}$ \\
\hline Bacillus pabuli & $13638^{\mathrm{T}}$ & NRRL NRS- $924^{T}$ \\
\hline Bacillus glucanolyticus & $15330^{\mathrm{T}}$ & DSM $5162^{\mathrm{T}}$, NCB $12809^{\mathrm{T}}$ \\
\hline Bacillus amylolyticus & $13625^{\mathrm{T}}$ & ATCC $9995^{\mathrm{T}}$ \\
\hline Bacillus alginolyticus & $15375^{\mathrm{T}}$ & NRRL NRS- $1347^{\mathrm{T}}$, DSM $5050^{\mathrm{T}}$ \\
\hline Bacillus chondroitinus & $15376^{\mathrm{T}}$ & NRRL NRS- $1351^{\mathrm{T}}$, DSM $5051^{\mathrm{T}}$ \\
\hline Bacillus lautus & $15380^{\mathrm{T}}$ & NRRL NRS-666 ${ }^{\mathrm{T}}$, DSM $3035^{\mathrm{T}}$ \\
\hline Bacillus parabrevis & $12334^{\mathrm{T}}$ & ATCC $10027^{\mathrm{T}}$ \\
\hline Bacillus choshinensis & $15518^{\mathrm{T}}$ & $\mathrm{JCM} 8505^{\mathrm{T}}$ \\
\hline Bacillus centrosporus & $15540^{\mathrm{T}}$ & NRRL NRS-664 $4^{\mathrm{T}}$ \\
\hline Bacillus agri & $15538^{\mathrm{T}}$ & NRRL NRS-1219 \\
\hline Bacillus macerans & $15307^{\mathrm{T}}$ & $\begin{array}{l}\text { ATCC } 8244^{\mathrm{T}}, \mathrm{JCM} 2500^{\mathrm{T}}, \\
\text { CCM } 2012^{\mathrm{T}}\end{array}$ \\
\hline Bacillus thiaminolyticus & $15656^{\mathrm{T}}$ & $\mathrm{JCM} 8360^{\mathrm{T}}$ \\
\hline
\end{tabular}

${ }^{a}$ Abbreviations for culture collections: IFO, Institute for Fermentation, Osaka, Osaka, Japan; ATCC, American Type Culture Collection, Rockville, Md.; NRRL, Northern Regional Research Center, U.S. Department of Agriculture, Peoria, Ill., DSM, Deutsche Sammlung von Mikroorganismen, Braunschweig, Germany; NCTC, National Collection of Type Cultures, Central Public Health Laboratory, London, England; NCIB, National Collection of Industrial and Marine Bacteria, Ltd., Aberdeen, Scotland: JCM, Japan Collection of Microorganisms, RIKEN, Wako, Saitama, Japan; CCM, Czech Collection of Microorganisms, Masarik University, Brno, Czech Republic.

rate group in the complex since the DNA $\mathrm{G}+\mathrm{C}$ contents of our strains were 50.1 to $51.8 \mathrm{~mol} \%$ and the $\mathrm{G}+\mathrm{C}$ contents of other members of the B. circulans complex were 37 to $54 \mathrm{~mol} \%$ (14).

The ability to hydrolyze polysaccharides is thought to be important in the classification of members of the $B$. circulans complex. For example, the names Bacillus amylolyticus (12), Bacillus alginolyticus (13) Bacillus chondroitinus (13), and $\mathrm{Ba}$ cillus glucanolyticus (1) were proposed on the basis of the abilities of the organisms to hydrolyze starch, alginic acid, chondroitin, and $\beta$-glucans (such as pustulan), respectively. We examined the abilities of our strains and related members of the $B$. circulans complex to hydrolyze $\beta$-glucans containing curdlan, cyclic $\beta$-1,2-glucan, carboxymethyl cellulose, and pustulan ( $\beta$-1,6-glucan) (Table 2 ). Our isolates hydrolyzed resistant curdlan, as well as regenerated curdlan and pustulan. Strain YK207 also hydrolyzed $\beta$-1,2-glucan. Strain WL-12, which had a lower DNA G+C content than our strains, hydrolyzed regenerated curdlan, but not resistant curdlan. There are many strains which hydrolyze regenerated curdlan among the organisms which have $\mathrm{G}+\mathrm{C}$ contents similar to or slightly lower than the DNA G+C contents of our strains. We selected B. glucanolyticus IFO $15330^{\mathrm{T}}$, Bacillus lautus IFO $15380^{\mathrm{T}}$, and $B$. circulans IFO 13157 as strains that are able to hydrolyze regenerated curdlan and pustulan and have DNA G+C contents similar to the $\mathrm{G}+\mathrm{C}$ contents of our strains. We also selected a strain of the $\mathrm{G}$ form of the $B$. circulans complex, IFO 15377 , which had a $G+C$ content similar to the $G+C$ contents of our strains, although this strain was not able to hydrolyze curdlan.

Table 3 shows characteristics which distinguish our organisms from related species. There are many differences between our strains and related organisms. One significant difference is the inability of our organisms to utilize the five organic acids tested. Acetate is utilized by all of the other organisms tested. Our organisms are not able to form acids from galactose, mannose, and ribose, but the other organisms which we studied produce acids from those sugars. Strains YK205 ${ }^{\mathrm{T}}$ and YK207 cannot produce acids from glycerol and raffinose, which distinguishes them from the other new strains.

Table 4 shows the levels of DNA relatedness between members of the $B$. circulans complex and related strains that hydrolyze curdlan. The group I strains (YK9 ${ }^{\mathrm{T}}$, YK122, YK161, YK201, YK203) exhibited high levels of DNA relatedness (more than $87 \%$ ) to strain $\mathrm{YK}^{\mathrm{T}}$, and the group II strains (YK205 ${ }^{\mathrm{T}}$, YK207) exhibited high levels of relatedness (more than $94 \%$ ) to strain YK205 ${ }^{\mathrm{T}}$. The group I and II strains exhibited low levels of DNA relatedness to the reference strains of the other species (less than 22 and $31 \%$, respectively).

Strains IFO 13157 (B. circulans), IFO $15380^{\mathrm{T}}$ (B. lautus; group $H$ of the $B$. circulans complex), and IFO $15330^{\mathrm{T}}(B$. glucanolyticus), which have DNA G+C contents of $51.4,50$ to 52 , and 48 to $50 \mathrm{~mol} \%$, respectively, and are able to hydrolyze resistant curdlan, exhibited low levels of DNA relatedness strains $\mathrm{YK} 9^{\mathrm{T}}$ and $\mathrm{YK} 205^{\mathrm{T}}$; the levels of relatedness between these strains and $\mathrm{YK} 9^{\mathrm{T}}$ were 12,8 , and $1 \%$, respectively, and the levels of relatedness between these strains and YK205 were 16, 11, and 3\%, respectively. Strain IFO 15377 (group G of the $B$. circulans complex), which had a $\mathrm{G}+\mathrm{C}$ content of 51 to $52 \mathrm{~mol} \%$ and was not able to hydrolyze curdlan, also exhibited low levels of DNA relatedness to strains $\mathrm{YK} 9^{\mathrm{T}}$ and YK205 ${ }^{\mathrm{T}}$ (12 and 13\%, respectively).

In addition to the DNA relatedness of strains belonging to the $B$. circulans complex, we also examined the DNA relatedness of six Bacillus strains that had DNA G + C contents of 49 to $54 \mathrm{~mol} \%$ (Table 4). One of these strains, strain IFO 15307 (Bacillus macerans), is able to hydrolyze curdlan. All of these strains exhibited less than $20 \%$ DNA relatedness to strains YK9 ${ }^{\mathrm{T}}$ and $\mathrm{YK} 205^{\mathrm{T}}$. Thus, all of the Bacillus strains which we tested exhibited low levels of DNA relatedness to the new isolates.

Next, we examined the whole-cell protein patterns of our isolates by performing sodium dodecyl sulfate-polyacrylamide gel electrophoresis (Fig. 2). The patterns of all of the group I strains (YK9 ${ }^{\mathrm{T}}$, YK122, YK161, YK201, YK203) were very similar to the $\mathrm{YK} 9^{\mathrm{T}}$ pattern, and the patterns of the two group II strains (YK205 ${ }^{\mathrm{T}}$, YK207) were very similar to each other; the 


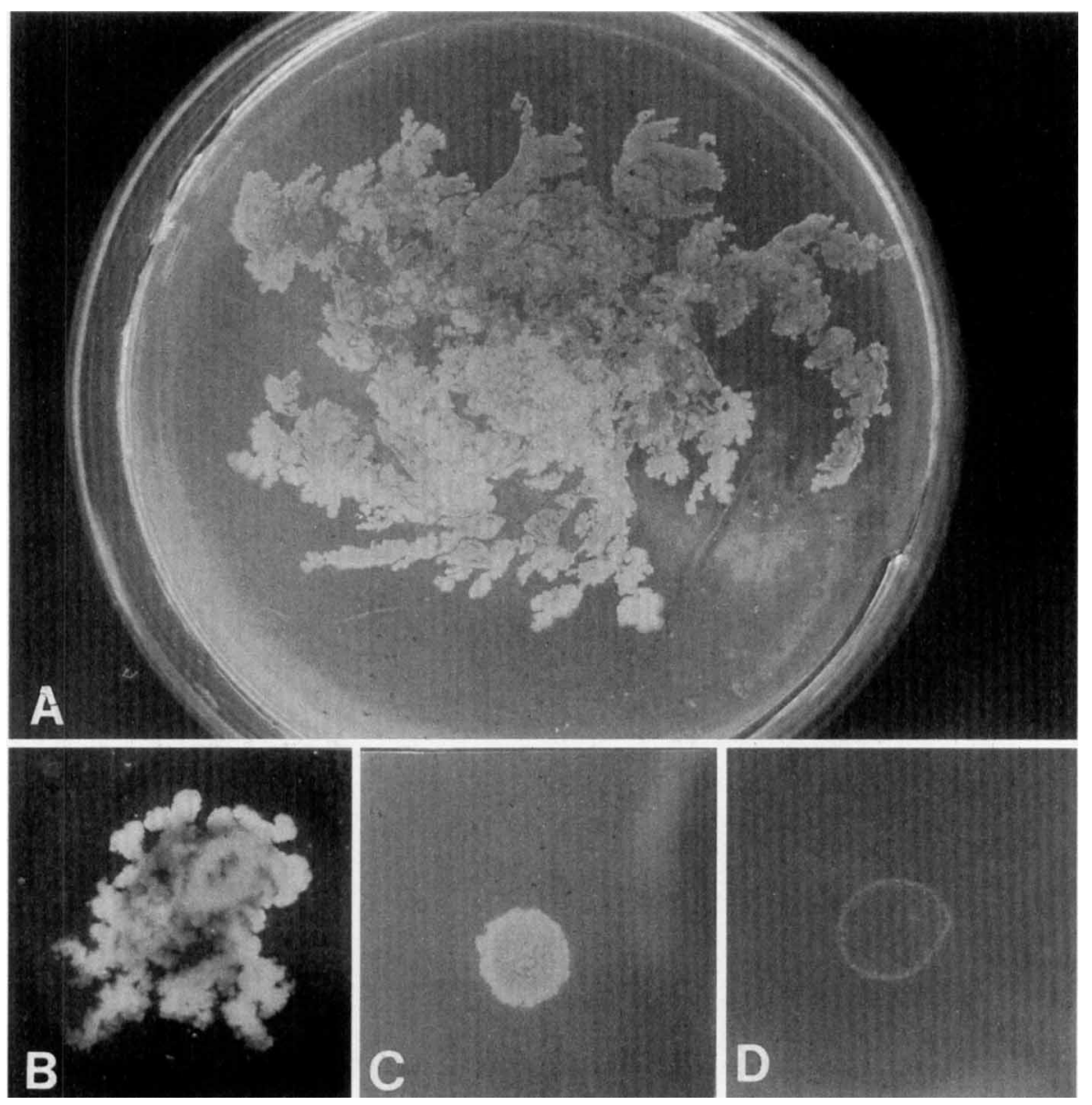

FIG. 1. Colonies of strain $\mathrm{YK}^{\mathrm{T}}$ grown on agar medium containing $0.5 \%$ glucose (A) or $0.5 \%$ curdlan (B) and inorganic salts (pH 7.2 ) and on agar medium containing $0.5 \%$ peptone and $0.5 \%$ yeast extract with $(\mathrm{C})$ or without (D) $0.5 \%$ glucose (pH 7.2 ). The photographs were taken after 10 days of incubation.

group I and II patterns were similar in many respects, but differed significantly in some bands.

One of the characteristics of the isolates which we studied is the ability to hydrolyze regenerated and resistant curdlans. The principal enzyme which hydrolyzes curdlan in $\mathrm{YK}^{\mathrm{T}}$ was purified, and its properties have been investigated previously by us (9). We found that the molecular mass of the protein of the enzyme is about $70 \mathrm{kDa}$, as judged by sodium dodecyl sulfatepolyacrylamide gel electrophoresis, and that the $\beta-1,3$-glucanase band is a major band in the pattern of $Y K 9^{\mathrm{T}}$ proteins obtained from a culture filtrate grown on curdlan-inorganic salts medium. This enzyme was found to be an exohydrolase which liberates $\alpha$-laminaribiose.

On the basis of the results described above, we propose two new species, Bacillus curdlanolyticus and Bacillus kobensis, for the organisms which we studied. Descriptions of these species are given below.

Description of Bacillus curdlanolyticus sp. nov. Bacillus curdlanolyticus (curd.lan. o. ly'ti. cus. Engl. n. curdlan, a polysaccharide produced by bacteria; Gr. adj. lyticus, dissolving; N.L. adj. curdlanolyticus, hydrolyzing curdlan). Cells are rod shaped ( 0.5 to 1.0 by 2.0 to $6.0 \mu \mathrm{m}$ ). Gram positive. Motile by means of peritrichous flagella. Ellipsoidal spores are formed in swollen sporangia. Colonies are flat, smooth, and opaque on nutrient agar plates and are motile during growth in synthetic medium containing glucose or curdlan and inorganic salts.
Colonies grow poorly in the absence of glucose or a carbon source. Aerobic. Catalase positive, but oxidase negative. The Voges-Proskauer reaction is negative, and the $\mathrm{pH}$ in VogesProskauer broth is 5.3 to 5.4. Hydrogen sulfide and indole are not produced. Nitrate is reduced to nitrite. Casein is not hydrolyzed, but urea is hydrolyzed. Curdlan, including resistant curdlan, pustulan, starch, and pullulan are hydrolyzed, but carboxymethyl cellulose and cyclic $1,2-\beta$-glucan are not hydrolyzed. Growth occurs in the presence of $0.001 \%$ lysozyme, but does not occur in the presence of $5 \% \mathrm{NaCl}$. No growth occurs at $50^{\circ} \mathrm{C}$. Acid but no gas is produced from glucose, fructose, xylose, L-arabinose, glycerol, sucrose, maltose, cellobiose, lactose, salicin, trehalose, and raffinose. Acid is not produced from galactose, mannose, rhamnose, ribose, melibiose, sorbitol, and mannitol. The major cellular fatty acid components are anteiso- $\mathrm{C}_{15: 0}$ and iso- $\mathrm{C}_{16: 0}$. The major quinone is menaquinone 7. The $\mathrm{G}+\mathrm{C}$ content ranges from 50 to $52 \mathrm{~mol} \%$. Habitat: isolated from soil.

The type strain is IFO 15724 (= YK9).

Description of Bacillus kobensis sp. nov. Bacillus kobensis (ko. ben'sis. M. L. adj. kobensis, referring to Kobe City, Hyogo Prefecture, Japan, the source of the soil from which the organisms were isolated.) Cells are rod shaped ( 0.5 to 1.0 by 2.0 to $6.0 \mu \mathrm{m}$ ). Gram positive. Motile by means of peritrichous flagella. Ellipsoidal spores are formed in swollen sporangia. Colonies are flat, smooth, and opaque on nutrient agar plates and 
TABLE 2. Hydrolysis of polysaccharides by Bacillus isolates that are able to hydrolyze resistant curdlan and related Bacillus strains

\begin{tabular}{|c|c|c|c|c|c|c|c|}
\hline \multirow[b]{2}{*}{ Strain } & \multirow[b]{2}{*}{ 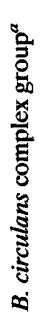 } & \multirow[b]{2}{*}{ 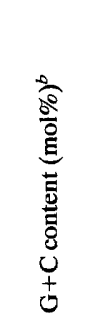 } & \multicolumn{5}{|c|}{ Hydrolysis of: } \\
\hline & & & 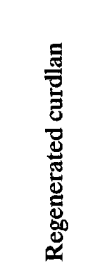 & 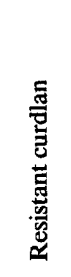 & 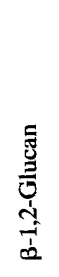 & 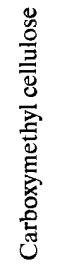 & 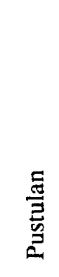 \\
\hline $\mathrm{YK}^{\mathrm{T}}$ & & 51.5 & $+++^{c}$ & ++ & - & - & + \\
\hline YK122 & & 51.2 & +++ & ++ & - & - & + \\
\hline YK161 & & 50.3 & +++ & ++ & - & - & + \\
\hline YK201 & & 51.2 & ++ & + & - & - & ++ \\
\hline YK203 & & 51.1 & ++ & + & - & - & ++ \\
\hline YK205 ${ }^{\mathrm{T}}$ & & 51.0 & ++ & + & - & - & ++ \\
\hline YK207 & & 51.8 & ++ & + & + & - & $+t$ \\
\hline B. alginolyticus IFO $15375^{\mathrm{T}}$ & $\mathrm{C}$ & $47-49$ & - & - & + & + & - \\
\hline B. amylolyticus IFO $13625^{\mathrm{T}}$ & $\mathrm{K}$ & 53 & + & - & - & - & + \\
\hline \multicolumn{8}{|l|}{ B. circulans } \\
\hline IFO 3967 & & 35.2 & - & - & - & - & - \\
\hline IFO $13626^{T}$ & A & $37-39$ & - & - & - & - & - \\
\hline IFO 13627 & & $37-39$ & - & - & - & - & - \\
\hline IFO 13628 & & $37-39$ & - & - & - & - & - \\
\hline IFO 13629 & & $37-39$ & - & - & - & - & - \\
\hline IFO 13634 & & $37-39$ & - & - & - & - & - \\
\hline IFO 13640 & & $37-39$ & - & - & - & - & - \\
\hline IFO 15378 & B & $45-47$ & - & - & - & - & - \\
\hline WL-12 & & 45.8 & +++ & - & + & + & + \\
\hline IFO 15379 & $\mathrm{~F}$ & $48-49$ & + & - & - & + & + \\
\hline IFO 13633 & & 49.0 & - & - & + & - & + \\
\hline IFO 13294 & & 49.9 & + & - & + & - & + \\
\hline IFO 13630 & & $49-50$ & ++ & - & - & - & - \\
\hline IFO 13632 & & 50.9 & - & - & + & - & - \\
\hline IFO 13639 & & 50.5 & + & - & + & + & + \\
\hline IFO 13157 & & 51.4 & +++ & ++ & - & - & + \\
\hline IFO 15377 & $\mathrm{G}$ & $51-52$ & - & - & - & - & - \\
\hline IFO 3329 & & 53.0 & - & - & - & + & - \\
\hline IFO 13637 & & $53-54$ & ++ & - & + & + & - \\
\hline IFO 13579 & & 55.5 & ++ & ++ & + & + & + \\
\hline B. chondroitinus IFO $15376^{\mathrm{T}}$ & D & 49.0 & - & - & - & + & - \\
\hline B. glucanolyticus IFO $15330^{\mathrm{T}}$ & & $48-50$ & +++ & - & + & + & + \\
\hline B. lautus IFO $15380^{\mathrm{T}}$ & $\mathrm{H}$ & $50-52$ & ++ & - & + & + & + \\
\hline \multirow{2}{*}{\multicolumn{8}{|c|}{ B. validus }} \\
\hline & & & & & & & \\
\hline IFO $15382^{\mathrm{T}}$ & I & $53-54$ & - & - & + & + & + \\
\hline IFO 13635 & & $53-54$ & - & - & + & + & - \\
\hline IFO 13636 & & $53-54$ & - & - & - & + & - \\
\hline
\end{tabular}

${ }^{a}$ See reference 2 .

${ }^{b}$ Data from this study and references 2 and 15 .

$c+++$,ytic zone more than $1 \mathrm{~cm}$ wide; ++ , lytic zone 0.5 to $1 \mathrm{~cm}$ wide; + , lytic zone 0.1 to $0.5 \mathrm{~cm}$ wide; - , no lytic zone. All data were obtained after incubation for 5 days. 
TABLE 3. Characteristics that distinguish the new soil isolates from related Bacillus species

\begin{tabular}{|c|c|c|c|c|c|c|}
\hline Characteristic & $\begin{array}{c}\text { Strains YK9 } \\
\text { YK122, YK161, } \\
\text { YK201, and YK203 }\end{array}$ & $\begin{array}{c}\text { Strains } \\
\text { YK205 } \\
\text { Thd } \text { YK207 }\end{array}$ & $\begin{array}{l}\text { B. glucanolyticus } \\
\text { IFO } 15330^{\mathrm{T}}\end{array}$ & $\begin{array}{l}\text { B. lautus IFO } \\
15380^{\mathrm{T}}\end{array}$ & $\begin{array}{l}\text { B. circulans } \\
\text { IFO } 15377\end{array}$ & $\begin{array}{l}\text { B. circulans } \\
\text { IFO } 13157\end{array}$ \\
\hline $\mathrm{G}+\mathrm{C}$ content $(\mathrm{mol} \%)$ & $50.1-51.8$ & $50.1-51.8$ & $48-49$ & $50-52$ & $51-52$ & 51.4 \\
\hline Anaerobic growth & - & - & + & + & - & $\mathrm{ND}^{a}$ \\
\hline Growth in the presence of $5 \% \mathrm{NaCl}$ & - & - & + & + & - & ND \\
\hline Growth with $0.001 \%$ lysozyme & + & + & ND & + & + & ND \\
\hline Nitrate reduction & + & + & + & + & - & ND \\
\hline $\mathrm{pH}$ in Voges-Proskauer broth of $<5.5$ & + & + & + & + & - & ND \\
\hline \multicolumn{7}{|l|}{ Hydrolysis of: } \\
\hline Curdlan & + & + & + & + & - & + \\
\hline Carboxymethyl cellulose & - & - & + & + & - & - \\
\hline Pustulan & + & + & + & + & - & + \\
\hline Starch & + & + & + & + & - & + \\
\hline Casein & - & - & ND & - & ND & ND \\
\hline Urea & + & + & - & + & - & - \\
\hline$\beta-1,2$-Glucan & - & $-(+)^{b}$ & + & + & - & - \\
\hline \multicolumn{7}{|l|}{ Production of: } \\
\hline Indole & - & - & - & - & - & - \\
\hline $\mathrm{H}_{2} \mathrm{~S}$ & - & - & - & - & - & - \\
\hline \multicolumn{7}{|l|}{ Utilization of: } \\
\hline Acetate & - & - & + & + & + & + \\
\hline Succinate & - & - & + & - & - & - \\
\hline Malate & - & - & + & - & - & + \\
\hline Fumarate & - & - & + & - & + & + \\
\hline Citrate & - & - & + & + & - & - \\
\hline \multicolumn{7}{|l|}{ Acid production from: } \\
\hline Glucose & + & + & + & + & + & + \\
\hline Fructose & + & + & + & + & - & - \\
\hline Galactose & - & - & + & + & + & + \\
\hline Mannose & - & - & + & + & + & + \\
\hline Rhamnose & - & - & + & + & + & - \\
\hline Xylose & + & + & + & + & + & - \\
\hline L-Arabinose & + & + & + & + & + & - \\
\hline Ribose & - & - & + & + & + & + \\
\hline Glycerol & + & - & + & - & - & + \\
\hline Sucrose & + & + & + & + & + & + \\
\hline Maltose & + & + & + & + & + & + \\
\hline Cellobiose & + & + & + & + & - & + \\
\hline Lactose & + & + & + & + & - & - \\
\hline Salicin & + & + & + & - & - & + \\
\hline Trehalose & + & + & + & + & + & + \\
\hline Melibiose & - & - & + & + & - & + \\
\hline Raffinose & + & - & + & + & - & - \\
\hline Sorbitol & - & - & - & - & - & - \\
\hline Mannitol & - & - & + & + & - & + \\
\hline
\end{tabular}

${ }^{a} \mathrm{ND}$, not determined.

${ }^{b}$ Strain YK207 hydrolyzed $\beta$-1,2-glucan. 
TABLE 4. Levels of DNA relatedness for members of the B. circulans complex that hydrolyze resistant curdlan

\begin{tabular}{|c|c|c|c|c|}
\hline \multirow[t]{2}{*}{ Strain } & \multirow{2}{*}{$\begin{array}{c}\mathrm{G}+\mathrm{C} \\
\text { content } \\
(\mathrm{mol} \%)\end{array}$} & \multirow[t]{2}{*}{$\begin{array}{c}\text { Curdlan } \\
\text { hydrolysis }\end{array}$} & \multicolumn{2}{|c|}{$\begin{array}{c}\% \text { Reassociation } \\
\text { with DNA } \\
\text { from }{ }^{a}:\end{array}$} \\
\hline & & & $\mathrm{YK}^{\mathrm{T}}$ & YK205 \\
\hline \multicolumn{5}{|l|}{ B. curdlano-lyticus } \\
\hline $\mathrm{YK} 9^{\mathrm{T}}$ & 51.5 & + & 100 & 31 \\
\hline YK122 & 51.2 & + & 89 & 25 \\
\hline YK161 & 50.3 & + & 97 & 29 \\
\hline YK201 & 51.2 & + & 97 & 27 \\
\hline YK203 & 51.1 & + & 87 & 26 \\
\hline \multicolumn{5}{|l|}{ B. kobensis } \\
\hline YK205 & 51.0 & + & 22 & 100 \\
\hline YK207 & 51.8 & + & 15 & 94 \\
\hline \multicolumn{5}{|l|}{ B. circulans complex } \\
\hline WL-12 & 45.8 & + & 9 & 12 \\
\hline IFO 13630 & $49-50$ & + & 7 & 7 \\
\hline IFO 13639 & 50.5 & + & 7 & 4 \\
\hline IFO 13632 & 50.9 & - & 9 & 9 \\
\hline IFO 13157 & 51.4 & + & 12 & 16 \\
\hline B. pabuli IFO $13638^{\mathrm{T} b}$ & $48-50$ & + & 10 & 11 \\
\hline B. circulans IFO $15379^{\circ}$ & $48-49$ & + & 11 & 13 \\
\hline B. circulans IFO $15377^{d}$ & $51-52$ & - & 12 & 13 \\
\hline B. lautus IFO $15380^{\mathrm{T} e}$ & $50-52$ & + & 8 & 11 \\
\hline B. validus IFO $15382^{\text {Tf }}$ & $53-54$ & - & 13 & 15 \\
\hline B. amylolyticus IFO $13625^{\mathrm{Tg}}$ & 53 & + & 10 & 12 \\
\hline B. glucanolyticus IFO $15330^{\mathrm{T}}$ & $48-50$ & + & 1 & 3 \\
\hline B. chondroitinus IFO $15376^{\mathrm{T}}$ & 49.0 & - & 12 & 8 \\
\hline B. circulans IFO $13579^{\mathrm{T}}$ & 55.5 & + & 15 & 14 \\
\hline B. parabrevis IFO $12334^{\mathrm{T}}$ & 50.0 & - & 8 & 8 \\
\hline B. choshinensis IFO $15518^{\mathrm{T}}$ & 49.1 & - & 8 & 7 \\
\hline B. centrosporus IFO $15540^{\mathrm{T}}$ & 50.3 & - & 19 & 13 \\
\hline B. agri IFO $15538^{\mathrm{T}}$ & 52.6 & - & 4 & 7 \\
\hline B. macerans IFO $15307^{\mathrm{T}}$ & 53.4 & + & 15 & 13 \\
\hline B. thiaminolyticus IFO $15656^{\mathrm{T}}$ & 52.6 & - & 15 & 11 \\
\hline
\end{tabular}

${ }^{a}$ The data are averages of values obtained from three determinations. The values from the three determinations differed by no more than $10 \%$.

${ }^{b} B$. circulans complex group E (2).

${ }^{c} B$. circulans complex group $\mathrm{F}(2)$.

${ }^{d} B$. circulans complex group $\mathrm{G}(2)$.

${ }^{e} B$. circulans complex group $\mathrm{H}(2)$.

${ }_{B}$. circulans complex group I (2)

${ }^{g}$ B. circulans complex group $\mathrm{K}(2)$

are motile during growth in synthetic medium containing glucose or curdlan and inorganic salts. Colonies grow poorly in the absence of glucose or a carbon source. Aerobic. Catalase positive, but oxidase negative. The Voges-Proskauer reaction is negative, and the $\mathrm{pH}$ in Voges-Proskauer broth is 5.3 to 5.4. Hydrogen sulfide and indole are not produced. Nitrate is reduced to nitrite. Casein is not hydrolyzed, but urea is hydrolyzed. Curdlan, including resistant curdlan, pustulan, starch, and pullulan are hydrolyzed, but carboxymethyl cellulose is not hydrolyzed. Hydrolysis of cyclic $1,2-\beta$-glucan is variable. Growth occurs in the presence of $0.001 \%$ lysozyme but does not occur in the presence of $5 \% \mathrm{NaCl}$. No growth occurs at $50^{\circ} \mathrm{C}$. Acid but no gas is produced from glucose, fructose, xylose, L-arabinose, sucrose, maltose, cellobiose, lactose, salicin, and trehalose. Acid is not produced from galactose, mannose, rhamnose, ribose, glycerol, melibiose, raffinose, sorbitol, and mannitol. The major cellular fatty acid components are anteiso- $\mathrm{C}_{15: 0}$ and iso- $\mathrm{C}_{16: 0}$. The major quinone is menaquinone 7 . The $\mathrm{G}+\mathrm{C}$ content ranges from 50 to $52 \mathrm{~mol} \%$. Habitat: isolated from soil.

The type strain is IFO 15729 (= YK205).

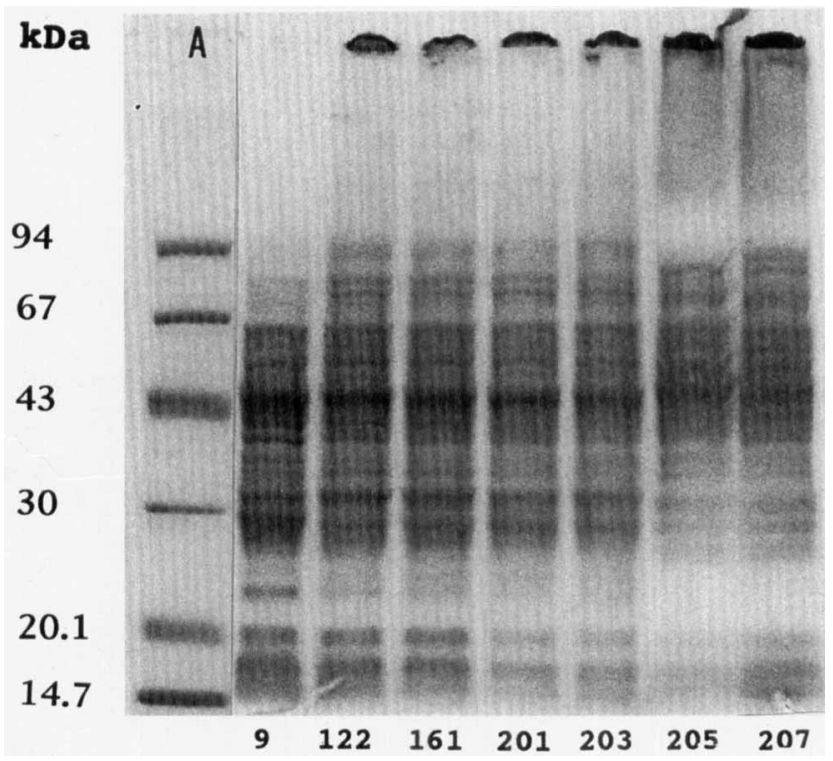

FIG. 2. Sodium dodecyl sulfate-polyacrylamide gel electrophoresis of the proteins in cells grown on medium containing $0.5 \%$ glucose and $0.5 \%$ yeast extract (pH 7.2). Lane A contained marker proteins (94-kDa phosphorylase $b$, $67-\mathrm{kDa}$ albumin, $43-\mathrm{kDa}$ ovalbumin, 30-kDa carbonic anhydrase, 20.1-kDa trypsin inhibitor, and $14.7-\mathrm{kDa} \alpha$-lactalbumin). Electrophoresis was carried out in a 10 to $20 \%$ polyacrylamide gel at $\mathrm{pH} 8.4$. The proteins were stained with Coomassie blue R-250.

\section{ACKNOWLEDGMENT}

We thank Toru Hasegawa, Institute for Fermentation, Osaka, for his valuable advice.

\section{REFERENCES}

1. Alexander, B., and F. G. Priest. 1989. Bacillus glucanolyticus, a new species that degrades a variety of $\beta$-glucans. Int. J. Syst. Bacteriol. 39:112-115.

2. Claus, D., and R. C. W. Berkeley. 1986. Genus Bacillus Cohn $1872,174^{\mathrm{AL}}, \mathrm{p}$ 1105-1138. In P. H. A. Sneath, N. S. Mair, M. E. Sharpe, and J. G. Holt (ed.), Bergey's manual of systematic bacteriology, vol. 2. The Williams and Wilkins Co., Baltimore.

3. Ezaki, T., Y. Hashimoto, and E. Yabuuchi. 1989. Fluorometric deoxyribonucleic acid-deoxyribonucleic acid hybridization in microdilution wells as an alternative to membrane filter hybridization in which radioisotopes are used to determine genetic relatedness among bacterial strains. Int. J. Syst. Bacteriol. 39:224-229.

4. Ezaki, T., Y. Hashimoto, H. Yamamoto, M. L. Lucida, S. L. Liu, S. Kusunoki, K. Asano, and E. Yabuuchi. 1990. Evaluation of the microplate hybridization method for rapid identification of Legionella species. Eur. J. Clin. Microbiol. Infect. Dis. 9:213-217.

5. Harada, T., K. Okuyama, A. Konno, A. Koreeda, and A. Harada. 1994. Effect of heating on formation of curdlan gels. Carbohydr. Polym. 24:101-106.

6. Harada, T., M. Terasaki, and A. Harada. 1993. Curdlan, p. 427-445. In R. L. Whistler and J. N. BeMiller (ed.), Industrial gums, 3rd ed. Academic Press, Inc., New York.

7. Kanzawa, Y., A. Harada, and T. Harada. 1991. Production of an enzyme capable of hydrolyzing resistant curdlan by soil bacteria. Home Econ. Jpn. 42:703-709.

8. Kanzawa, Y., T. Harada, A. Koreeda, A. Harada, and K. Okuyama. 1989. Difference of molecular association in two types of curdlan gel. Carbohydr. Polym. 10:299-313.

9. Kanzawa, Y., T. Kurasawa, T. Kanegae, A. Harada, and T. Harada. 1994. Purification and properties of a new exo- $(1 \rightarrow 3)$ - $\beta$-D-glucanase from Bacillus circulans YK9 capable of hydrolyzing resistant curdlan with formation of only laminaribiose. Microbiology (Washington, D.C.) 140:637-642.

10. Komagata, K., and K. Suzuki. 1987. Lipid and cell-wall analysis in bacterial systematics. Methods Microbiol. 19:161-207.

11. Laemmli, U. K. 1970. Cleavage of structural proteins during the assembly of the head of bacteriophage T4. Nature (London) 227:680-685.

12. Mesba, M., U. Premachandran, and W. B. Whitman. 1989. Precise measurement of the $\mathrm{G}+\mathrm{C}$ content of deoxyribonucleic acid by high-performance liquid chromatography. Int. J. Syst. Bacteriol. 39:159-167.

13. Nakamura, L. K. 1984. Bacillus amylolyticus sp. nov., nom. rev., Bacillus lautus sp. nov., nom. rev., and Bacillus validus sp. nov., nom. rev. Int. J. 
Syst. Bacteriol. 34:224-226.

14. Nakamura, L. K. 1987. Bacillus alginolyticus sp. nov. and Bacillus chondroitinus sp. nov., two alginate-degrading species. Int. J. Syst. Bacteriol. 37:284286.

15. Nakamura, L. K., and J. Swezey. 1983. Deoxyribonucleic acid relatedness of Bacillus circulans Jordan 1890 strains. Int. J. Syst. Bacteriol. 33:703-708

16. Saito, H., and K. Miura. 1963. Preparation of transforming deoxyribonucleic acid by phenol treatment. Biochim. Biophys. Acta 72:619-629.

17. Stone, B. A., and A. E. Clarke. 1992. Enzymes depolymerizing $(1 \rightarrow 3)-\beta$ - glucans, p. 117-209. In B. A. Stone and A. E. Clarke (ed.), Chemistry and biology of $(1 \rightarrow 3)-\beta$-glucans. Trobe University Press, Victoria, Australia

18. Takagi, H., O. Shida, K. Kadowaki, K. Komagata, and S. Udaka. 1993. Characterization of Bacillus brevis with descriptions of Bacillus migulanus $\mathrm{sp}$. nov, Bacillus choshinensis sp. nov., Bacillus parabrevis sp. nov., and Bacillus galactophilus sp. nov. Int. J. Syst. Bacteriol. 43:221-231.

19. Takahashi, F., T. Harada, A. Koreeda, and A. Harada. 1986. Structure of curdlan that is resistant to $(1 \rightarrow 3)-\beta$-D-glucanase. Carbohydr. Polym. 6:407421. 